可視化情報 Vol.24 Suppl. No.2（2004 年 9月）

B 123

\title{
ミリ波レーダによる濃煙空間の計測・可視化手法の検討
}

\author{
$\dagger †$ 大峯 幸雄○†酒井 正樹 †青木 義満 ††高木 幹雄 \\ $\dagger$ 芝浦工業大学工学部 情報工学科 \\ $\dagger \dagger$ 芝浦工業大学大学院 電気工学尃攻 \\ E-mail: $\uparrow\{$ mine, sakai, aoki\}@aoki-medialab.org
}

†† mikio@sic.shibaura-it.ac.jp

\section{Examination of the measurement / visualization technique of the dark smoke space by the millimeter wave radar}

\author{
†† Yukio Omine†Masaki Sakai†Yoshimitsu Aoki††Mikio Takagi
}

\begin{abstract}
In this paper, we aim at visualizing smoke-filled space in front of fire crews using millimetric wave radar sensor. Our proposed system is composed of the millimetric-wave radar, a stereo camera, and gyroscope sensor attached on them. Millimetric wave has a property of filtering out smoke. The FM-CW millimetric-wave radar can output a $2 \mathrm{D}$ reflection density values from obstacles for one-time scanning in invisible space. As for visible space by eyesight, we utilize the $3 \mathrm{D}$ stereo camera which can capture a $3 \mathrm{D}$ distance map with color information in an angular field of view. Both of the sensors have the capable of real-time scanning (10 frames/sec), and we manually operate them to scan target space. The scanned frame data is stored with 3D direction information from a gyroscope sensor. To construct the 3D space map, we integrate the 2D maps from the millimetric'wave radar and the $3 \mathrm{D}$ maps from the stereo camera using the gyroscope data.
\end{abstract}

Keywords : Smoke space visualization, Millimetric-wave radar, Gyroscope sensor, 3D space reconstruction

\section{1.はじめに}

\section{1 研究背景}

近年、日本国内だけではなく、世界的に自然災害や人 的災害が急増している。このような現状の中、それらの 災害に対してどのような危機管理を行うかが重要な課題 となっており，工学技術を応用した各種セキュリティシ ステムの研究開発が行われている。特に火災発生現場に おける救急活動においては，炎同棣に作業上大きな障害 となるのが，眼前に立ち込める煙である。濃度の高い煙 の存在は, 消防隊員の空間把握能力を大きく低下させる。 現状，このような状況下において，消防隊員は手に検索 棒という発光する棒を持ち、周囲の物体や人の体に当た る感触を探りながら救助活動を行っている。そこで，立 ち込める煙を見透かし，空間の 3 次元地図を得ることが できれば，救助活動の大きな手助けとなる。
人間が立ち入ることのできない，危険度の高い災害発 生現場における救急活動においては，様々な計測センサ を搭載した救助・探索用ロボットの利用が検討されてい る[1][2]。その一例として, 濃煙空間の中の障害物を探 索し, 状況把握を行うロボットが提案されている[3]。し かし, 刻々と地面や周辺の状況が変化する環境下におい て，迅速な状況判断と移動性が求められることが多く， 解決す心゙き課題も多い。濃煙空間内にいる消防隊員自身 がセンサを身に付け，現場の状況認識を支援するような システムは未だ開発されていない。

\section{2 研究目的}

本研究では，火災現場における救命・消火活動におい て、作業員による現場の状況把握が最も重要な問題であ ると考え、煙が立ち込める 3 次元空間（濃煙空間）を可 視化することを目的とする。可視や熱赤外領域の計測手 
段では不可能である濃煙空間内での 3 次元計測には, 自 動車の前方車両検知センサとして開発されている小型の ミリ波レーダ装置を用い, 手振りにより多数方向の奥行 きデータを取得する。同時に得られたジャイロセンサの 方位情報を元に距離データを統合し, 空間の 3 次元地図 を作成する。得られた 3 次元地図を可視化・提示するこ とで消防隊員の空間認識能力を増強させるのが提案する 計測システムの目的である。全体の処理の流れを図 1 に 示す。

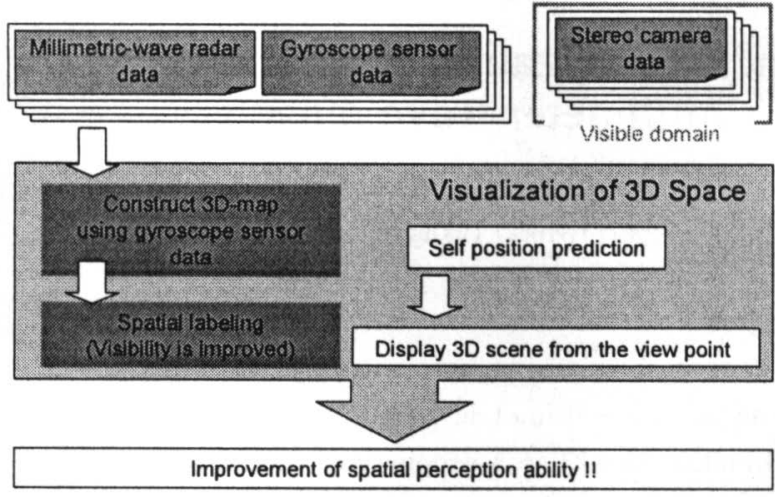

Fig 1 The overall processing of the system

本稿では, 主に提案する計測システムの概要と, ミリ波 レーダの空間 3 次元計測の適用可能性について述べる。 検証実験では，煙のない空間での 3 次元計測及び空間の 構築を行い, 計測システムの基本的な性能ついて検討し た。

\section{2. 計測システム}

本計測機器の概要を図 2 に示す。

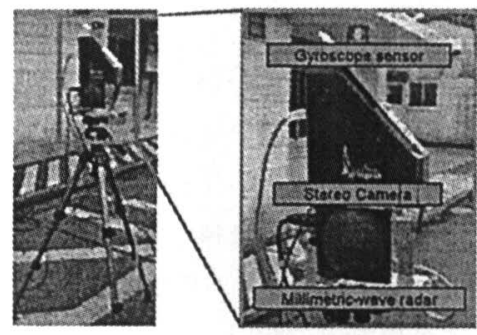

Fig2 External appearance of the measuring system

\section{1 ミリ波レーダ}

濃煙空間における奥行き計測には, 前方車両との距離 計測用レーダとして使用されている、76GHz 帯ミリ波レ ーダを用いる。測距方式は FMCW 方式であり，検知エリア 内のターゲットの距離、相対速度、角度情報、信号強度 のデータを出力することが可能である。濃霧や雨など, 悪天候下においてもロバストな計測が可能なことから， 濃煙環境下での距離計測への適用を検討している。

\subsection{1煙に対する透過性}

煙のようにミリ波の波長に比べ微小な粒子では以下の
レイリー散乱近似が成り立つことが知られている。波長 の 4 乗に反比例して散乱が増加する(透過しなくなる)。 ミリ波の波長に対して、煙の粒子は非常に小さいので、 光波と比べて散乱しにくく，透過しやすい性質を持って いる。現在, 自動車で実用化されているミリ波レーダは 霧や雨, 雪などに対しても強い耐性を示しており, 煙が 充満する空間中でも同様に計測が可能であると考える。

$$
\begin{aligned}
& \sigma=4\left(\frac{2 \pi a}{\lambda}\right)^{4}\left(\pi a^{2}\right) \\
& \sigma: \text { Rear scattering cross-section area } \\
& \text { a : Particle radius Lambda } \\
& \lambda: \text { Wavelength }
\end{aligned}
$$

\subsection{2 測距方法}

FMCW レーダは連続波の送信信号（CW）に周波数変調 （FM）を施したものを用いる。送信信号として, 図 3 上 の実線で示すように周波数変調を三角波の繰り返しで施 したものを使うとすると, 距離 R のところにある目標か らの反射信号の周波数は図 3 上の点線のように変化する このとき，送信信号と反射信号のビート周波数（送信信 号と反射信号の周波数差）は図 3 下のようになる。この とき反射信号のビート周波数と目標距離には (2) 式の関 係があり, ビート周波数を検知することにより対象物体 までの距離が得られる。

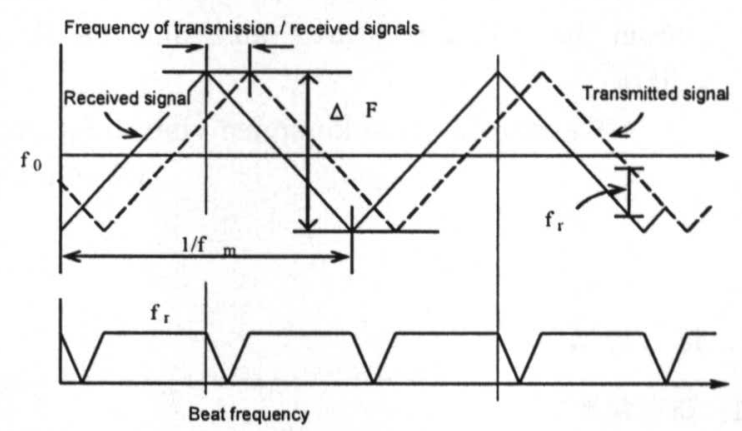

Fig3 Relationship between distance and transmission / received signals

$$
\begin{aligned}
& \mathrm{R}=\frac{\mathrm{C}}{4 \cdot \Delta \mathrm{F} \cdot \mathrm{f}_{\mathrm{m}}} \cdot \mathrm{f}_{\mathrm{r}} \\
& \mathrm{R}: \text { Distance to target } \mathrm{fr}: \text { Beat frequency } \\
& \mathrm{C}: \text { Light speed } \\
& \mathrm{fm}: \text { Modulation frequency } \\
& \cdot \mathrm{F}: \text { Amplitude of frequency modulation }
\end{aligned}
$$

また装置は、一次元走査により, 一度で得られるデー 夕 (1フレーム) は水平 1 ライン $\pm 10^{\circ}, 0.55^{\circ}$ 間隔 38 ビーム, 1 ピーム当り $0.5 \mathrm{~m}$ 間隔で 384 点から構成され る信号強度データである (図 4)。データ取得レートは最 高 $10 \mathrm{~Hz}$ であり, 動的な距離計測が可能である。 レーダ出カデータは FFT 処理されたパワースペクトルで 
ある。信号強度レベルに応じて各計測点を色分けし，3 次元空間中に反射強度情報付きの点群データとして配置 する。

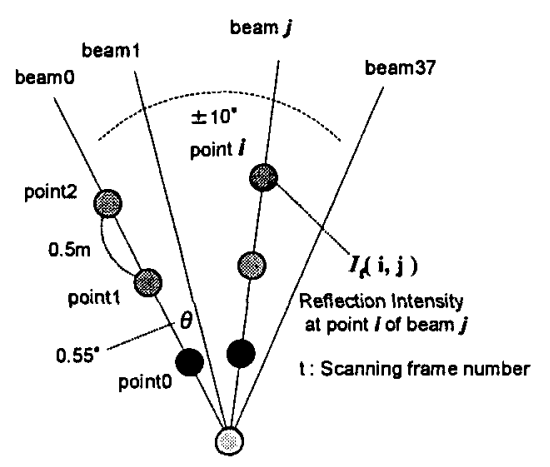

Fig4 Radar data acquirable by 1 -dimensional scan

\section{3 次元空間の構築手法}

ミリ波レーダによって1回の一次元走査で得られる点 群データは図 4 に示した通りであり,空間解像度が低い。 そこで，ミリ波レーダを複数の場所から様々な方向一向 けて走查し, 点群データの空間解像度を向上させる。走 查毎に得られた信号強度付きの点群データを 3 次元空間 中に統合するには，観測者の位置（正確にはレーダアン テナの放射開始点）と姿勢を計測する必要がある。姿勢 の計測には 3 軸方位角が計測可能なジャイロセンサ (Inertia2/Intersense 社) を用い，スキャン時の 3 軸 角度デー夕（yaw, pitch, roll）を得る。また，位固の検 出に関しては加速度センサと地磁気センサを利用したデ ッドレコニングによる推定手法を検討中である。推定さ れた観測者の 3 次元位㯰及び姿勢情報位置の原点 3 次元 空間を構築する際、重要となってくるのは角度データで ある。計測する際、ミリ波レーダ、ステレオカメラは三 脚に固定してジャイロセンサを三脚の回転軸の中心に固 定する。固定した支点から水平方向に角度を振って断続 的にデータを取得していく際、ジャイロセンサにより角 度データ (yaw, pitch, roll) を取得する。

計測位置iにおいて，n回の走查により信号強度データ を取得した場合を考える。ミリ波レーダの放射開始点を 原点としたローカル座標系における信号強度データを $I_{t}(x, y, z)$ ：ジャイロの 3 軸回転角度及び推定位置によ り座標変換を施した後のワールド座標系における信号強 度データを $I_{t}\left(X_{w}, Y_{w}, Z_{w}\right)$ とすると, 計測位置iにおいて得 られた点群データ $\xi_{i}$ 及び全ての計測位貣において得ら れたデータを統合した点群データ集合は図 5 の通りに表 される。ステレオ計測の結果得られた距離データに対し ても同様に計測位置及び姿勢データを用いて点群データ を統合し 3 次元マップを生成する。

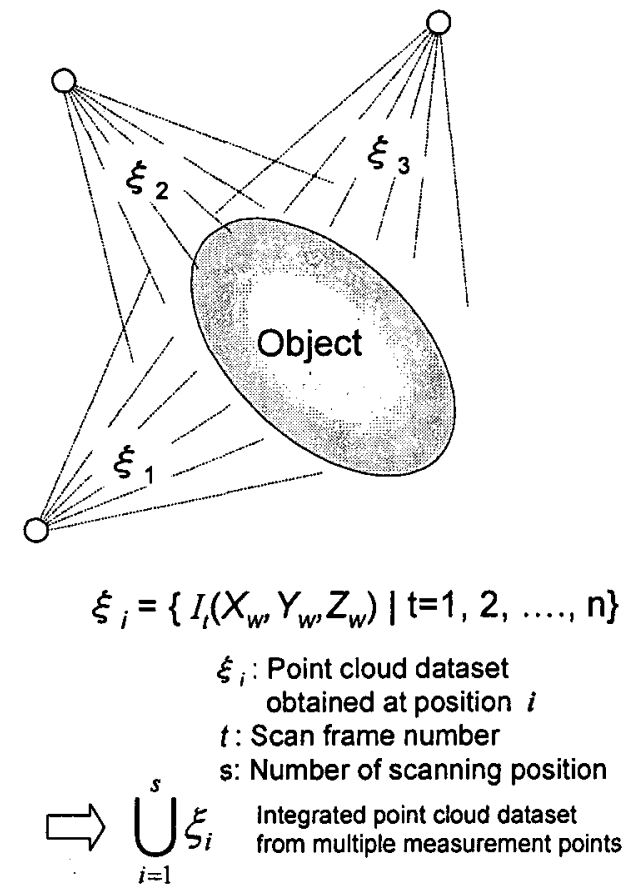

Fig5 Integration of point cloud datasets

\section{4：実験と考察}

\section{1 実験概要}

、今回，室外において固定された 1 地点から装置を三脚 に設置した上で回転させて断続的にデータを取得して 3 次元構築した実験（4.2），また，複数の地点から装置 を連続的に手振りし，3 次元計測する寒験（4.3）を実施 した。室外においては人、自動車、建築物がある環境で、 ミリ波レーダ、ステレオカメラ両機器による計測と 3 次 元空間の可視化を行った。なお，今回の実験は全て煙の ない環境下での実験である。

\section{2 屋外空間の計測実験}

屋外の実験では、人物を 2 人配直し、計測を行った。 計測装置の位置を三脚で一箇所に固定し，水平方向に $15^{\circ}$ 、垂直方向に- $10^{\circ} \sim 10^{\circ}$ までを $10^{\circ}$ 刻みで回転さ せ，各ヶの姿勢においてデータの取得を行った。取得し たミリ波レーダの信号強度データを3 章の手法により 3 次元空間内にマッピングする。また、ステレオカメラで 計測した 3 次元マップをミリ波レーダの計測結果検証の ために用いる。ミリ波レーダから得た 3 次元地図とステ レオカメラから構築した 3 次元地図との対応を図 6 に示 す。左右の壁面及び人物の存在位置に強い反射信号が得 られた。2名の人物は $2 \mathrm{~m}$ 離れて立っていたが,データの 分布から両者をセグメンテーションすることができた。 建物の入り口付近から内部に関してレーダの反射データ が取得されていることから、レーダの多重反射により計 測箇所から不可視な領域（オクルージョン）に対しても ミリ波が到達し，対象物を捕らえられる可能性があるこ とがわかった。 


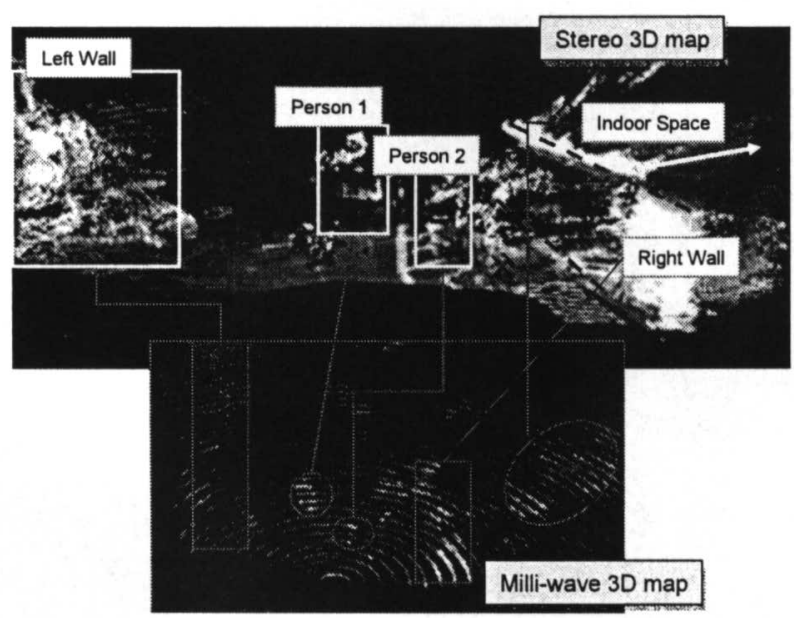

Fig6 The measurement result in the outdoors

\section{3 複数地点からの手振りによる計測}

4 章で述べた目標とする実用化の形態に最も近い, セ ンサを可視化したい空間へ向けて手振りし，連続的にス キャンして空間解像度を高める基礎的な実験を行った。 実験環境は屋外で，図 7 に示すように人物を囲む矩形領 域の辺上に 6 点を設定し, 計測地点既知の条件のもと, 各地点において計測装置を人物の存在する方向へ 6 秒間 ずつ走査した。ミリレーダのフレームレートは $10 \mathrm{~Hz}$ とし た。予めステレオ計測してステレオの 3 次元地図を構築 しておき、それとミリ波レーダデータより検出された信 号強度の高い点群データを重ね合わせ, 検証を行った。 結果を図 8 に示す。

多地点から手振りでデータを連続取得したことによ り, 人物の前後の表面上に点群データを得ることができ た。ステレオ計測の結果と照合した結果, 人物の幅・奥

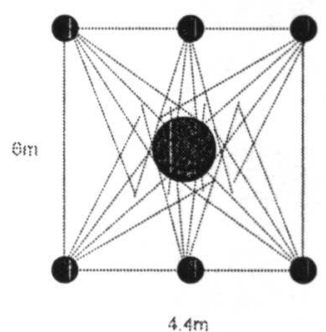

Fig7 Experiment environment

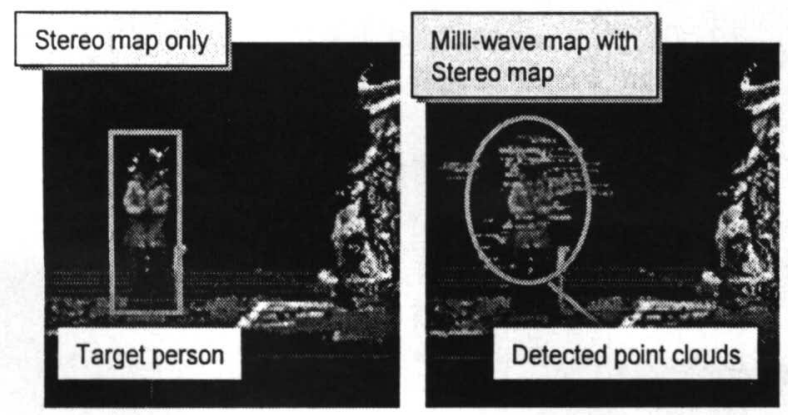

Fig 8 The result measured by shaking manually
行きに関して実際の人物の大きさと同等の値を得ること ができた。人物の周辺までデータに広がりが見えるが， この主な原因は装置を振った際の位置ずれ，角度検出の 誤差であると考えられる。

\subsection{3 次元ラベリング処理による視認性の向上}

図8(右)のように、装置を振った際の位置ずれや角度 検出の誤差で生じたデータが人物周辺まで広がっている ため、視認性が低い。そこで、3 次元空間内に仮想的な 3 次元ブロックを用意し、各ブロック内の信号強度の出 現頻度、信号強度の総和、点群の 3 次元的な連結性を算 出し、閾值処理によって各ブロックを表示、または、消 去することで、人物周辺のノイズデータを除去すること ができ、視認性を高めることができる。

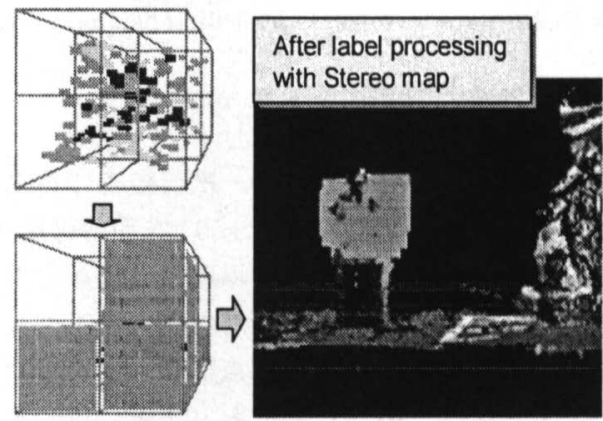

Fig9 After label processing

\section{5.まとめ}

火災現場における救命・消火活動において、煙が立ち 込める空間（濃煙空間）を可視化するシステム実現へ向 けての基礎的な検討を行った。ミリ波レーダから得られ た距離情報とジャイロセンサの方位情報を統合すること で，可視や熱赤外領域の計測手段では不可能である濃煙 可視化を目指している。本稿では, 煙のない状況でミリ 波レーダの 3 次元計測適用の可能性を検証した。その結 果, 空間解像度に問題は残るものの, 人物や壁面などの 対象物を検出可能であることがわかった。また空間的な ラベリング処理を施すことにより、視認性を高めること ができた。(図 9)

今後の課題としては, 加速度センサ情報からの位置推 定処理の実装, 構築した 3 次元地図情報のわかりやすい 提示方法などがある。また，実際に煙の存在する空間に おいて実証実験を実施し、システムの評価を行う予定で ある。

\section{参 考 文 献}

1) http://www.mie.eng.himeji-tech.ac.jp/manufl/inchworm/inchi worm/robot.html

2) http://www.c-crews.co.jp/gnext express/news/back/0308/0308 22 .05. html

3) http://www.tfd.metro.tokyo.jp/ts/soubi/robo/03.htm 